\title{
DAMPAK INTERVENSI PENDIDIKAN "GI-PSI-SEHAT" BAGI IBU TERHADAP KONSUMSI PANGAN DAN STATUS GIZI ANAK USIA DINI
}

\author{
Siti Madanijah ${ }^{1}$ \\ ${ }^{1}$ Staf pengajar Dept. Gizi Masyarakat, FEMA -IPB \\ ABSTRACT

\begin{abstract}
THE IMPACT OF EDUCATION MODEL "GI-PSI-SEHAT" (NUTRITIONPSYCHOSOSIAL-HEALTH) FOR MOTHER ON FOOD CONSUMPTION AND NUTRITIONAL STATUS OF CHILDREN UNDER TWO YEAR
\end{abstract}

The objective of this study is to develop and to analyze the education wholistic model (NutritionPsychosocial-Health) in order to build good food consumption pattern for children through the improvement of mother's behaviour. A quasi experiment, nonrandomized control group pretest posttest design study, of the impact of the education model "GI-PSI-SEHAT" (NutritionPsychosocial-Health) has been carried out at urban area in Bogor, West Java. The total of respondent are 131 primiparous mothers of children of 0-11 months, who are selected by purposive sampling technique, which consist of 66 mothers in control group and 65 mothers in intervention group, who participated in the intervention programme. During five months, education model "GI-PSI-SEHAT" was conducted by face to face method, in groups or individually, with combination of teaching techniques i.e. speech, discussion, simulation, practical and home visit. Teaching aids i.e. booklets, flip-chart, food-models, and real things was used in order to increase the effectiveness of the programme. The study reveals that the intervention of "GI-PSI-SEHAT" improves food consumption pattern, whether in punctuality, food diversification, or the frequency of food consumption. In eight months time, the intervention enable the increase of the Mean Adequacy Ratio (MAR) as an overall measure of the nutrient adequacy. The impact of the intervention of "GI-PSI-SEHAT" is decrease of z-score of weight-for-age and height-for-age of the intervention group is lower than the control group, especially for children under 12 month. Classification and regression tree statistical analysis demonstrated that independent variables have strong association with response variables. Nutritional status of mother based on Body Mass Index (BMI) is the dominant variable associated with nutritional status of children based on z-score of weight for age, on the other hand Mean Adequacy Ratio (MAR) is the dominant variable associated with nutritional status of children based on z-score of height for age. Wholistic education model "GI-PSI-SEHAT" for mothers with some modification may applicable at another area, especially for community with low education level.

Keywords: nutrition education, children under two years, complementary feeding, food consumption pattern, nutritional status.

\section{PENDAHULUAN}

ertumbuhan dan perkembangan anak usia dini berdampak pada kualitas manusia jangka pendek dan jangka panjang (ACC/SCN, 2000). Masalah gizi kurang pada anak usia dini berdampak negatif jangka panjang yang mahal Myers (1995), Smith \& Haddad (2000).

Masa-masa awal kehidupan anak merupakan masa kritis (the golden years), dimana terjadi pertumbuhan dan perkembangan yang sangat cepat. Pertumbuhan dan 
perkembangan anak sangat ditentukan oleh faktor pengasuhan anak. Unicef (1998) menekankan pentingnya pengasuhan dan perawatan anak, dan menempatkan kurangnya perawatan anak sebagai unsur ketiga penyebab kurang gizi, disamping ketidakcukupan pangan dan pelayanan kesehatan.

Pertumbuhan anak erat kaitannya dengan konsumsi pangan, sehingga perlu diperhatikan makanan anak yang memenuhi kebutuhan zat gizi (Latham, 1997; Pipes, 1996a; Pipes, 1996b). Makanan pendamping ASI yang diberikan mulai umur 4-6 bulan secara bertahap sesuai perkembangan kemampuan bayi merupakan komponen penting untuk gizi yang baik (Dep. of Health, 1995; WHO, 1998; WHO, 2003).

Anak bawah dua tahun (baduta) merupakan konsumen pasif yaitu belum dapat mengambil dan memilih makanan sendiri, sukar diberikan pengertian tentang makanan serta kemampuan mereka untuk menerima berjenis makanan masih terbatas (Santrock, 1997). Dengan keterbatasan kemampuan tersebut, kebutuhan ini hanya dapat dipenuhi dengan bantuan orang lain.

Pemberian makan kepada anak tidak hanya merupakan pemenuhan kebutuhan gizi, tetapi merupakan pengalaman sosial (Myers, 1995). Penerapan cara makan yang baik pada anak sejak usia dini akan sangat menentukan kebiasaan makannya pada saat remaja atau dewasa (Fieldhouse, 1995; Birch \& Fisher, 1998).

Pendidikan gizi merupakan promosi efektif kepada konsumen mengenai konsumsi pangan dan gizi yang baik (Rinke, 1986; Tontisirin et all, 1994), dapat meningkatkan pengetahuan gizi, mempertahankan sikap positif dan memperbaiki kebiasaan gizi ibu (Cerquiera \& Olson, 1995). Dengan melibatkan ibu dalam program perbaikan gizi anak, memberi dampak lebih baik terhadap pola makan anak, dibanding tanpa melibatkan ibu (Kirks \& Hughes, 1986).

Intervensi gizi dan kesehatan telah dilakukan secara mendunia, namun upaya peningkatan pengetahuan dan perbaikan gizi yang dilaksanakan di Indonesia belum dilakukan secara holistik yang memadukan berbagai aspek, terutama pendidikan, gizi dan kesehatan. Perlu strategi yang memadukan aspek gizi, kesehatan dan psikososial dengan basis keluarga (Myers, 1995; Zeitlin et al, 1995). Terdapat tiga institusi yang berperan dalam upaya peningkatan kualitas anak usia dini, yaitu keluarga (Behrman, 1995), masyarakat dan pemerintah (Mock et al, 2000). Optimalisasi peran ketiganya akan memberikan hasil yang terbaik.

Berdasarkan uraian di atas, penelitian ini dilakukan untuk mengetahui dampak pendidikan yang memadukan ketiga aspek tersebut (gizi, psikososial dan kesehatan: "GI-PSI-SEHAT") pada ibu terhadap pembentukan pola konsumsi pangan dan status gizi pada anak usia dini.

\section{Tujuan Penelitian}

Secara umum penelitian ini bertujuan untuk mengembangkan dan menilai model pendidikan "GI-PSI-SEHAT" untuk pembentukan kebiasaan makan pada anak usia dini, yang berdampak pada konsumsi pangan dan status gizi. Tujuan khusus penelitian adalah untuk menganalisis:

1. Dampak intervensi pendidikan "GI-PSISEHAT" terhadap tingkat konsumsi pangan dan pola konsumsi pangan anak.

2. Dampak intervensi pendidikan "GI-PSISEHAT" terhadap status gizi anak.

\section{Kegunaan Penelitian}

Hasil penelitian ini diharapkan dapat digunakan bagi penentu kebijakan dan praktisi untuk mendapatkan model pendidikan gizi khususnya dalam pengasuhan anak dan pemberian makan serta sebagai pedoman bagi ibu rumahtangga dalam cara pengasuhan, khususnya pemberian makan.

\section{Kerangka model penelitian}

Kerangka model penelitian dapat dilihat pada Gambar 1. Masa awal kehidupan seorang anak merupakan periode paling kritis. Sebagai konsumen pasif anak perlu perhatian dalam pemberian makan, yang 
dilakukan oleh ibu. Karakteristik ibu (umur, pendidikan, dan akses informasi) diduga berpengaruh terhadap peubah keluaran (output) yaitu perilaku ibu, lingkungan pembelajaran dan pola asuh. Peubah Keluaran diduga dapat ditingkatkan juga dengan pemberian intervensi pendidikan "GI-PSI-SEHAT". Analisis mengenai peubah keluaran tidak disajikan dalam tulisan ini.

Peubah keluaran berpengaruh terhadap Peubah Dampak (outcome), yaitu pola konsumsi pangan (ketepatan waktu pemberian, keragaman jenis makanan dan frekuensi konsumsi), konsumsi pangan (ASI dan MPASI) dan status gizi. Konsumsi pangan diukur dengan tingkat konsumsi energi, protein, kalsium, fosfor, besi, vitamin $A$, vitamin C dan Vitamin B1 serta NRKG. Status gizi dan kesehatan anak merupakan salah satu indikator dari tumbuh kembang anak. Status gizi diukur secara antropometri (BB/U, PB/U dan BB/PB), sedangkan tingkat kesehatan anak dilihat dari imunisasi dan kejadian sakit. Karakteristik anak yang menentukan status gizi meliputi berat dan panjang badan saat lahir, jenis kelamin, umur dan riwayat kesehatan anak.

\section{BAHAN DAN CARA}

\section{Desain dan Kerangka Contoh}

Penelitian ini menggunakan desain Quasi-Experimental, Nonrandomized Control Group Pretest-Posttest Design (Isaac dan Michael, 1990), yaitu penelitian dilakukan pada populasi dengan memberikan intervensi pada kelompok perlakuan, serta pengukuran sebelum dan sesudah intervensi. Tahapan penelitian meliputi Pengumpulan Data Dasar, Penerapan Model Pendidikan "GI-PSI-SEHAT" dan Pengukuran Dampak.

Pengumpulan Data Dasar dilakukan terhadap keluarga contoh, untuk mengetahui karakteristik keluarga, ibu dan anak. Selanjutnya pemberian intervensi Model Pendidikan Gizi (gizi, psikososial, dan kesehatan). Pengukuran Dampak meliputi pengukuran hasil pendidikan gizi dan dampak terhadap pola konsumsi pangan dan status gizi anak.

Penelitian dilakukan di tiga kelurahan Kecamatan Bogor Timur, Kota Bogor, yaitu Kelurahan Baranangsiang, Katulampa dan Sukasari, yang ditentukan secara purposif. Intervensi Pendidikan "GI-PSI-SEHAT" dilakukan selama lima bulan efektif.

Sesuai tujuan penelitian, maka contoh penelitian adalah bayi laki-laki atau perempuan beserta ibunya dengan karakteristik sebagai berikut : 1) berumur 011 bulan; 2) anak pertama; 3) dari ibu berumur kurang dari 35 tahun; 4) ibu tidak bekerja; dan 5) pengasuhan oleh ibunya pada sebagian besar waktu pengasuhan.

Penentuan contoh dilakukan melalui pendataan pada setiap posyandu di masingmasing kelurahan terpilih. Dari sebanyak 373 orang anak umur 0-11 bulan, 188 orang anak merupakan anak pertama, dan 142 anak yang ibunya tidak bekerja serta mengasuh sendiri anaknya. Jumlah tersebut seluruhnya dipakai sebagai contoh penelitian, dengan dua kelompok contoh yaitu 1) Kelompok Kontrol (KK) dan 2) Kelompok Intervensi (KI) yaitu kelompok yang mendapat intervensi pendidikan "GIPSI-SEHAT". Sampai dengan akhir penelitian jumlah contoh sebanyak 132, yaitu KK 66 orang dan KI 65 orang; jumlah ini digunakan untuk analisis selanjutnya.

\section{Pengumpulan Data}

Data yang dikumpulkan meliputi: 1) karakteristik keluarga, ibu dan anak; 2) konsumsi pangan anak dan status gizi anak. Data karakteristik keluarga dilakukan dengan wawancara menggunakan kuesioner terstruktur, data pemberian ASI dan MPASI dilakukan dengan wawancara disertai observasi, data konsumsi pangan anak dengan metode recall, berat badan dan panjang badan anak dilakukan dengan pengukuran langsung, status gizi ibu diukur dengan indikator indeks massa tubuh (IMT). Pengumpulan data tersebut dilakukan sebelum dan setelah intervensi pendidikan "GI-PSI-SEHAT" dibantu enumerator yang telah dilatih. 
Pelaksanaan Intervensi "GI-PSI-SEHAT"

Sasaran Pendidikan "GI-PSI-SEHAT"

adalah ibu dari anak yang dijadikan contoh, berjumlah 65 orang.

Metode dan Teknik Pendidikan Gizi: menggunakan metode tatap muka secara kelompok dan pembinaan secara individu melalui kunjungan rumah. Kegiatan tatap muka secara kelompok dilakukan selama dua jam setiap kali pertemuan dengan frekuensi pertemuan dua kali seminggu, selama 1,5 bulan, dengan jumlah pertemuan sebanyak 12 kali. Fungsi utama dari teknik kunjungan rumah pada program intervensi menurut Powell (1999) adalah mendorong ibu untuk melakukan aktivitas yang mendorong perkembangan anak.

Teknik yang digunakan merupakan kombinasi dari berbagai teknik, yaitu ceramah, simulasi, peragaan, dan praktek. Untuk meningkatkan efektifitas pengajaran, digunakan alat bantu : 1) Buku Modul atau Paket Penyuluhan : Gizi, Psikososial dan Kesehatan (disingkat GI-PSI-SEHAT) yang terdiri dari Buku I dan Buku II; 2) lembar balik (flip chart) 3) contoh makanan (food models); dan 4) alat permainan edukatif.

Materi Pendidikan Gizi. Materi pendidikan meliputi ketiga aspek, yaitu Gizi, Psikososial dan Kesehatan yang diberikan secara terintegrasi meliputi: SDM yang Berkualitas, Makanan Sehat dan Bergizi, ASI: Makanan Bayi Terbaik, Cara Pemberian ASI, Makanan Pendamping ASI, Cara Pemberian Makanan Pendamping ASI, Cara Pembuatan Makanan Bayi, Kesulitan Makan pada Bayi, Pertumbuhan Anak, Perkembangan Anak, dan Perawatan Bayi. Materi berkaitan dengan stimulasi Psikososial diberikan secara terpadu dengan kedua aspek lainnya.

\section{Pengolahan dan Analisis Data}

Pengolahan Data

1. Data pola konsumsi pangan dinilai dengan skor.

2. Data konsumsi pangan dikonversikan ke dalam kandungan energi dan zat gizi menggunakan perangkat lunak NUTRISOFT.
Analisis Data

1. Uji kesetaraan dilakukan terhadap peubah bebas, yaitu karakteristik keluarga, karakteristik ibu, dan karakteristik anak antara KK dan Kl.

2. Uji kesetaraan antara peubah respon pada prauji antara KK dan KI.

3. Uji beda dilakukan terhadap peubah respon purnauji antara KK dan $\mathrm{Kl}$.

4. Metode CART (Classification and Regression Tree) digunakan untuk mengetahui faktor dominan yang berpengaruh terhadap peubah respon yaitu peubah dampak (pola konsumsi pangan, konsumsi pangan, dan status gizi anak)

5. Analisis regresi dilakukan terhadap peubah dominan yang dihasilkan dari metode CART.

\section{HASIL DAN BAHASAN}

\section{Karakteristik Keluarga}

Secara umum karakteristik keluarga contoh pada kedua kelompok relatif sama. Rata-rata umur ibu 23 tahun dan umur ayah 27 tahun. Keluarga contoh masih termasuk keluarga muda, karena berdasarkan kriteria contoh dalam penelitian ini adalah anak pertama. Lama pendidikan ibu rata-rata 9 tahun (tamat SLTP), dan lama pendidikan ayah 10 tahun. Lebih dari 50\% keluarga merupakan keluarga kecil dengan jumlah anggota keluarga tiga orang.

Rata-rata pendapatan keluarga KK adalah $\mathrm{Rp}$ 187.367/kapita/bulan, yang lebih tinggi dibandingkan pada $\mathrm{KI}$ yaitu $\mathrm{Rp}$ 157.442/kapita/ bulan. Masih terdapat keluarga contoh berada di bawah garis kemiskinan, yaitu 19,7\% (KK) dan 13,8\% (KI). Rata-rata alokasi pengeluaran untuk pangan masih relatif tinggi yaitu hampir $60 \%$. Skor pemilikan aset relatif sama, yaitu KK 18,1 dan KI 17,9.

Keadaan lingkungan fisik keluarga contoh, yang dilihat dari kebersihan rumah dan halaman, sumber air dan keadaan air minum, udara dan pencahayaan dalam rumah, serta pemilikan dan keadaan jamban, 
menunjukkan bahwa secara umum keadaan lingkungan fisik keluarga tidak berbeda antara kedua kelompok. Penilaian dengan skor menunjukkan skor lingkungan fisik KK sebesar 26,29 dan KI sebesar 26,25.

Pada awal penelitian sebagian besar ibu $(94 \%$ KK dan $91 \% \mathrm{KI})$ dalam status fisiologis menyusui, dan semua ibu pada saat tersebut tidak sedang hamil, karena umur anak masih sangat muda. Status gizi ibu dengan indikator indeks massa tubuh (IMT), sebagian besar ibu ( $83 \% \mathrm{KK}$ dan $85 \%$ $\mathrm{KI})$ termasuk status gizi normal, namun sebanyak 11\% ibu KK dan 19\% KI termasuk kurus, bahkan 1,5\% KK dan 6,2\% KI kurus sekali.

Dalam hal akses informasi gizi dan kesehatan, 30\% ibu sama sekali belum terjangkau informasi khususnya gizi, kesehatan dan pengasuhan. Penilaian dengan skor menunjukkan hampir sama antara KK dan $\mathrm{KI}$ yaitu 22,4 dan 21,4 yang secara statistik tidak berbeda.

Anak yang dijadikan contoh dalam penelitian ini berumur 0 sampai 11 bulan. Anak umur 9-11 bulan lebih banyak pada $\mathrm{KK}$, sedangkan kelompok umur muda (0 - 2 bulan) lebih banyak pada KI. Pada kedua kelompok proporsi anak laki-laki 55\%, relatif lebih besar dibanding perempuan (45\%).

\section{Konsumsi Pangan \\ Kerangka Konseptual}

Determinan penting yang mempengaruhi status gizi anak adalah konsumsi pangan dan keadaan kesehatan atau infeksi. Konsumsi pangan anak umur di bawah dua tahun adalah ASI dan MPASI. ASI yang dikonsumsi oleh anak kuantitas dan kualitasnya dipengaruhi oleh frekuensi, lama pemberian ASI, status gizi ibu dan kesehatan ibu. Sedangkan konsumsi MPASI dipengaruhi oleh karakteristik ibu, keadaan sosial ekonomi keluarga dan pemberian makan.

\section{Pengukuran dan Penilaian Konsumsi Pangan}

Konsumsi pangan anak meliputi pemberian ASI dan MPASI, serta konsumsi energi dan zat gizi. Data pola konsumsi pangan anak meliputi jenis, frekuensi dan saat pemberian makan diperoleh dengan metode recall selama dua hari berturut-turut. Konsumsi ASI digunakan estimasi sebagai berikut (Tabel 1).

Tabel 1

Estimasi Konsumsi ASI menurut Kelompok Umur

\begin{tabular}{|c|c|c|c|}
\hline \multirow{2}{*}{$\begin{array}{c}\text { Kelompok Umur } \\
\text { (bulan) }\end{array}$} & \multicolumn{3}{|c|}{ Estimasi Konsumsi ASI (Kkal) } \\
\cline { 2 - 4 } & Rendah & Sedang & Tinggi \\
\hline $0-2$ & 279 & 437 & 595 \\
$3-5$ & 314 & 474 & 634 \\
$6-8$ & 217 & 413 & 609 \\
$9-11$ & 157 & 379 & 601 \\
$12-23$ & 90 & 346 & 602 \\
\hline
\end{tabular}

Sumber: WHO (1998)

Penentuan ASI rendah, sedang atau tinggi, selain berdasarkan frekuensi dan lama menyusui, juga berdasarkan status konsumsi ASI-MPASI secara keseluruhan sebagai berikut (Tabel 2). 
Tabel 2

Penentuan Status Konsumsi ASI

\begin{tabular}{|l|c|}
\hline \multicolumn{1}{|c|}{ Status Konsumsi ASI-MPASI } & Status Konsumsi ASI \\
\hline ASI saja & Tinggi \\
ASI + MPASI & Sedang \\
ASI + Susu Formula + MPASI & Sedang \\
Susu Formula + MPASI & Rendah \\
\hline
\end{tabular}

Kandungan zat gizi lainnya dari ASI dihitung dengan cara konversi kandungan energi dan zat gizi ASI sebagai berikut (Tabel 3).

Selanjutnya data konsumsi pangan dikonversikan ke dalam nilai energi dan zat gizi, yaitu protein, vitamin $A$, vitamin $C$ dan tiamin, serta mineral kalsium, fosfor, dan besi, dengan menggunakan DKBM (Departemen Kesehatan, 1995; Hardinsyah \& Briawan, 1990). Khusus MPASI produk industri, kandungan gizinya dihitung berdasarkan komposisi zat gizi yang ada dalam kemasan makanan/minuman tersebut.

Tabel 3

Estimasi Kandungan Energi dan Zat Gizi dari ASI

\begin{tabular}{|l|c|c|}
\hline \multirow{2}{*}{ Zat Gizi } & \multicolumn{2}{|c|}{ Kandungan } \\
\cline { 2 - 3 } & Per liter ${ }^{1)}$ & Per 100 $\mathrm{g}^{2)}$ \\
\hline Energi (Kkal) & 681 & 66 \\
Protein (g) & 10,5 & 1,02 \\
Kalsium (mg) & 280 & 27,2 \\
Fosfor (mg) & 140 & 13,6 \\
Besi (mg) & 0,30 & 0,03 \\
Vitamin A (RE) & 500 & 48,5 \\
Vitamin C (mg) & 40 & 3,9 \\
Vitamin B1 (mg) & 0,21 & 0,02 \\
\hline
\end{tabular}

Kecukupan energi dan protein anak dihitung berdasarkan pada angka kecukupan energi dan protein individu menurut umur dan BB sehat anak (Hardinsyah \& Martianto 1988). Angka kecukupan gizi yang dianjurkan adalah sebagai berikut (Tabel 4).

Tingkat konsumsi energi dan zat gizi (TKG) anak merupakan perbandingan antara konsumsi energi dan zat gizi dengan angka kecukupannya, dinyatakan dalam persentase. Mutu gizi konsumsi pangan berdasarkan perhitungan delapan jenis zat gizi pangan yang dikonsumsi oleh anak, dinyatakan sebagai Nilai Rata-rata tingkat Konsumsi Gizi (NRKG).

NRKG $\geq 100 \%$ : mutu gizi baik dan NRKG $<100 \%$ : mutu gizi kurang. 
Tabel 4

Angka kecukupan Energi dan Zat gizi yang Dianjurkan per Orang per Hari (WKNPG 2004)

\begin{tabular}{|c|c|c|c|c|c|c|c|c|c|}
\hline $\begin{array}{c}\text { Kel } \\
\text { Umur } \\
\text { (bulan) }\end{array}$ & $\begin{array}{c}\text { Berat } \\
\text { Badan } \\
(\mathrm{kg})\end{array}$ & $\begin{array}{c}\text { Energi } \\
(\text { Kkal) }\end{array}$ & $\begin{array}{c}\text { Protein } \\
(\mathrm{g})\end{array}$ & $\begin{array}{c}\text { Vit. A } \\
(\mathrm{RE})\end{array}$ & $\begin{array}{c}\text { Tiamin } \\
(\mathrm{mg})\end{array}$ & $\begin{array}{c}\text { Vit. C } \\
(\mathrm{mg})\end{array}$ & $\begin{array}{c}\text { Kalsium } \\
(\mathrm{mg})\end{array}$ & $\begin{array}{c}\text { Fosfor } \\
(\mathrm{mg})\end{array}$ & $\begin{array}{c}\text { Besi } \\
(\mathrm{mg})\end{array}$ \\
\hline $0-6$ & 6,0 & 550 & 10 & 375 & 0,3 & 40 & 200 & 100 & 0.3 \\
$7-11$ & 8,5 & 650 & 16 & 400 & 0,4 & 50 & 400 & 225 & 10 \\
$12-36$ & 12,0 & 1000 & 23 & 400 & 0,5 & 40 & 500 & 400 & 7 \\
\hline
\end{tabular}

\section{Pola Pemberian Air Susu Ibu}

Sebagian besar ibu (83\%) memberikan kolostrum pada bayi begitu anak lahir. Pemberian kolostrum memberikan banyak manfaat, karena mengandung zat gizi bermutu tinggi, antibodi, dan membiasakan bayi minum dari payudara ibu, Makanan prelakteal yang berupa madu, pisang, gula merah, kuning telur ataupun air tajin, diberikan pada bayi baru lahir sebelum ASI keluar oleh sekitar $60 \%$ ibu. Hal ini memberikan indikasi kurangnya pengetahuan ibu dan adanya kebiasaan yang tidak menguntungkan, bahkan dapat membahayakan bayi.

Hampir semua ibu memberikan ASI kepada bayinya sejak lahir. $\mathrm{Hal}$ ini merupakan suatu hal yang positif, karena ASI mempunyai banyak keunggulan dibanding susu formula, antara lain yang terpenting adalah terdapatnya zat kekebalan bagi tubuh. Demikian pula hampir semua ibu (92-98,5\%) pada awal penelitian dan $91 \%$ KK dan $85 \%$ KI pada akhir penelitian masih memberikan ASI.

Lebih dari $90 \%$ ibu menyusui tanpa jadwal, sedangkan sisanya menyusui secara terjadwal, yaitu setiap 2-3 jam. Frekuensi menyusui sangat beragam. Frekuensi menyusui anak prauji pada KK relatif lebih banyak dibanding KI yaitu rata-rata 10,7 dan 9,2 kali per hari, sedangkan purnauji relatif sama, yaitu 9,8 dan 9,1 kali per hari. Selain frekuensi, lama menyusui juga turut menentukan konsumsi ASI. Rata-rata lama menyusui prauji hampir sama antara kedua kelompok yaitu 16,7 menit pada KK dan 17,2 menit pada $\mathrm{KI}$, sedangkan purnauji anak pada KK lebih lama menyusu (17,9 menit) dibanding pada KI (13 menit).

\section{Pola Pemberian Makanan Pendamping ASI (MPASI)}

Pada awal penelitian (39-55\%) ibu telah memberikan susu formula, yang mulai diberikan pada umur yang sangat muda. Pada umur 0-3 bulan, hampir 50\% telah menerima susu formula, lebih dari $40 \%$ mulai umur dua minggu atau kurang, selanjutnya sekitar $20 \%$ mulai umur 1-3 bulan. Penggunaan susu formula pada usia yang masih sangat muda, apalagi pada hari-hari pertama kelahiran, dapat berakibat buruk antara lain bayi bingung puting sehingga tidak bisa menyusu pada ibunya, dan bayi terbiasa minum susu botol. Pada KK ada peningkatan proporsi ibu yang memberikan susu formula, tetapi pada $\mathrm{KI}$ terdapat penurunan. Hal ini menunjukkan intervensi pendidikan mengurangi penggunaan susu formula pada bayi.

Sebagian besar (lebih dari 80\%) ibu pada awal penelitian sudah memberikan MPASI kepada bayinya selain susu formula. Pada akhir penelitian semua anak di kedua kelompok telah memperoleh MPASI. Pemberian MPASI yang terlalu dini dapat memberikan dampak negatif pada anak, karena organ-organ pencernaan anak belum berkembang secara optimal.

Pengertian ASI eksklusif adalah pemberian ASI saja tanpa minuman atau makanan lain sampai bayi berumur empat bulan. Pada awal penelitian, berdasarkan 
data jumlah anak umur empat bulan ke atas, pemberian ASI eksklusif hanya terdapat pada $24 \%(\mathrm{KK})$ dan $18 \%(\mathrm{KI})$. Dibandingkan dengan angka nasional yaitu status ASI eksklusif sebesar $25 \%$, angka ini pada KK adalah sama, sedangkan pada KI lebih kecil. Pada akhir penelitian status ASI eksklusif pada KK lebih baik dibanding Kl; yaitu sebesar $29 \%$, lebih besar dibanding angka nasional, sedangkan pada KI lebih kecil yaitu $21,5 \%$.

\section{Dampak Intervensi terhadap Pola Konsumsi Pangan}

Pola konsumsi pangan anak dinilai dengan skor pada setiap kelompok pangan terhadap tiga aspek, yaitu aspek ketepatan waktu pemberian, keragaman jenis, dan frekuensi konsumsi. Pada akhir penelitian, ada peningkatan nilai skor pola konsumsi pangan sebesar $30 \%$ pada $\mathrm{KI}$, sedangkan pada KK terjadi penurunan sebesar $29 \%$ (Tabel 5).

Tabel 5

Rata-rata Nilai Pola Konsumsi Pangan Prauji dan Purnauji

\begin{tabular}{|l|c|c|c|c|c|c|c|c|}
\hline \multirow{2}{*}{ Aspek } & \multicolumn{4}{|c|}{ KK $(\mathrm{n}=66)$} & \multicolumn{4}{c|}{$\mathrm{KI}(\mathrm{n}=65)$} \\
\cline { 2 - 9 } Pola Konsumsi Pangan & \multicolumn{3}{|c|}{ Nilai Pola Konsumsi Pangan } & \multicolumn{4}{c|}{ Nilai Pola Konsumsi Pangan } \\
\cline { 2 - 9 } & Pra & Purna & Perub & $\%$ Perub & Pra & Purna & Perub & $\%$ Perub \\
\hline Ketepatan Waktu & 50,5 & 45,1 & $-5,4$ & $-10,7$ & 50,4 & 55,8 & 5,4 & 10,7 \\
Keragaman Jenis & 52,5 & 38,1 & $-14,4$ & $-27,4$ & 48,4 & 62,8 & 14,4 & 29,8 \\
Frekuensi & 50,6 & 38,8 & $-11,8$ & $-23,3$ & 50,2 & 62,1 & 11,9 & 23,7 \\
\hline Total & 51,8 & 37,0 & $-14,8$ & $-28,6$ & 49,1 & 64,0 & 14,9 & 30,3 \\
\hline
\end{tabular}

Pada akhir penelitian, nilai skor ketepatan waktu pemberian makanan pada $\mathrm{KI}$ lebih tinggi dibanding KK. Hal ini menggambarkan bahwa pemberian makanan pada KI lebih tepat waktu. Ketepatan waktu berarti pemberian suatu jenis makanan sesuai dengan umur anak. Demikian pula dalam hal keragaman jenis pangan, yang menunjukkan bahwa jumlah jenis makanan yang diberikan pada anak KI lebih banyak. Makin baiknya pola konsumsi pangan anak juga terlihat dari frekuensi konsumsi yang lebih sering pada KI.

\section{Faktor-faktor yang Berasosiasi dengan Pola Konsumsi Pangan}

Peubah yang berasosiasi dengan pola konsumsi pangan anak adalah umur anak dan pendapatan keluarga. Umur anak yang semakin tua, pola makan semakin baik. Hal ini berkaitan dengan ketepatan waktu pemberian makan dan kemampuan anak mengkonsumsi jenis pangan yang lebih beragam. Pendapatan keluarga berhubungan negatif dengan pola konsumsi pangan. Konsumsi Energi dan Zat Gizi
Rata-rata konsumsi energi dan protein ASI dan MPASI anak KK adalah 969 Kkal dan 23,4 g, sedangkan pada KI 839 Kkal dan 21,1 g protein per orang per hari. Tingkat konsumsi energi (TKE) dan tingkat konsumsi proten (TKP) anak pada KI lebih rendah dibanding $\mathrm{KK}$, sedangkan tingkat konsumsi vitamin (kecuali vitamin $\mathrm{B}_{1}$ ) dan mineral pada $\mathrm{KI}$ lebih tinggi. MPASI terutama susu formula banyak memberikan kontribusi terhadap konsumsi energi dan zat gizi.

Dampak Intervensi terhadap Konsumsi Energi dan Zat Gizi

Dampak intervensi terhadap konsumsi pangan anak dapat dilihat dari perubahan mutu gizi konsumsi pangan (NRKG). NRKG anak prauji dan purnauji termasuk baik. Pada KI NRKG purnauji relatif lebih baik dibanding KK. Walaupun masih terdapat anak dengan NRKG yang buruk pada $\mathrm{Kl}$, namun jumlahnya lebih sedikit (3\%) dibanding pada KK (14\%). Setelah intervensi, proporsi anak dengan NRKG yang buruk menurun dari $8 \%$ menjadi $3 \%$ pada $\mathrm{KI}$, sedangkan pada $\mathrm{KK}$ meningkat dari $6 \%$ menjadi $14 \%$ (Tabel 6 ). 
Faktor-Faktor yang Berasosiasi dengan Konsumsi Energi dan Zat Gizi

Tingkat konsumsi energi dan protein berasosiasi negatif dengan peubah dominan frekuensi konsumsi jenis pangan.
Sedangkan faktor yang berhubungan dengan TKE adalah tingkat pendidikan ibu, kejadian sakit ISPA dan alokasi waktu ibu dengan anak. TKE anak akan semakin tinggi dengan meningkatnya pendidikan ibu.

Tabel 6

Rata-rata Nilai TKE \& Zat Gizi dan NRKG

\begin{tabular}{|l|c|c|c|c|c|c|c|c|}
\hline \multirow{2}{*}{ Kelompok Gizi } & \multicolumn{5}{|c|}{ KK $(\mathrm{n}=66)$} & \multicolumn{4}{c|}{ KI (n=65) } \\
\cline { 2 - 8 } & Prauji & Purnauji & Perub & Perub (\%) & Prauji & Purnauji & Perub & Perub (\%) \\
\hline Energi & 107,24 & 101,57 & $-5,66$ & $-5,28$ & 130,44 & 91,78 & $-38,66$ & $-29,64$ \\
Protein & 134,20 & 141,47 & 7,27 & 5,41 & 175,33 & 128,68 & $-46,65$ & $-26,61$ \\
Kalsium & 99,75 & 79,91 & $-19,84$ & $-19,89$ & 160,28 & 87,09 & $-73,18$ & $-45,66$ \\
Fosfor & 107,30 & 138,15 & 30,85 & 28,75 & 166,40 & 137,44 & $-28,96$ & $-17,40$ \\
Besi & 96,01 & 85,10 & $-10,91$ & $-11,37$ & 175,84 & 95,96 & $-79,88$ & $-45,43$ \\
Vitamin A & 176,64 & 193,98 & 17,33 & 9,81 & 168,92 & 283,16 & 114,24 & 67,63 \\
Vitamin C & 135,66 & 104,70 & $-30,96$ & $-22,82$ & 190,58 & 122,27 & $-68,30$ & $-35,84$ \\
Vitamin B1 & 161,71 & 275,57 & 113,86 & 70,41 & 194,44 & 177,85 & $-16,58$ & $-8,53$ \\
\hline NRKG & 127,32 & 140,06 & 12,74 & 10,01 & 170,28 & 140,54 & $-29,74$ & $-17,47$ \\
\hline
\end{tabular}

Sedangkan faktor lain yang berasosiasi dengan TKP yaitu umur anak, akses ibu terhadap informasi, aset yang dimiliki, ketepatan imunisasi dan tingkat pendidikan ibu. Selanjutnya peubah yang paling dominan berasosiasi dengan NRKG purnauji adalah TKP; semakin tinggi TKP, semakin tinggi pula NRKG.

\section{Status Gizi Anak}

Kerangka Konseptual

Status gizi merupakan keadaan kesehatan tubuh seseorang yang diakibatkan oleh tingkat konsumsi, penyerapan dan penggunaan zat gizi makanan. Penentuan status gizi anak secara antropometri dapat dilihat dari indikator berat badan menurut umur (BB/U), panjang badan menurut umur $(\mathrm{PB} / \mathrm{U})$ dan berat badan menurut panjang badan (BB/PB). BB/U merupakan indikator yang cukup handal terutama bila digunakan untuk umur 0-2 tahun dan PB/U merupakan indikator yang tepat yang merefleksikan status gizi masa lampau, dan BB/PB merupakan indikator global status gizi. Status gizi dipengaruhi oleh dua determinan, yaitu intik zat gizi dan keadaan kesehatan.
Pengukuran dan Penilaian Status Gizi dan Kesehatan Anak

Penilaian Status Gizi

Penghitungan status gizi anak dengan ukuran antropometri berat dan tinggi badan anak diolah menggunakan standar WHONCHS (National Center for Health Statistics) dengan menghitung Z-skor. Penghitungan status gizi menggunakan rumus Z-skor sebagai berikut (WHO 1983).

Dimana:

$$
\mathrm{Zsci}=\frac{(\mathrm{Xi}-\mathrm{Mi})}{\mathrm{M}-(-1 \mathrm{SD})}
$$

$$
\begin{aligned}
\mathrm{i} \quad= & \text { jenis ukuran antropometri yang } \\
& \text { dipakai, yaitu BB/U, PB/U atau } \\
& \text { BB/PB. } \\
\mathrm{X}= & \mathrm{BB} \text { atau PB aktual } \\
\mathrm{M} \quad= & \text { median dari standar WHO-NCHS } \\
\mathrm{SB} \quad= & \text { Simpangan baku }
\end{aligned}
$$

Klasifikasi status gizi anak berdasarkan $\mathrm{BB} / \mathrm{U}, \mathrm{PB} / \mathrm{U}$ dan BB/PB. Status gizi ibu dihitung dengan menggunakan ukuran indeks massa tubuh (IMT), dengan rumus:

$$
\text { IMT }=\frac{\text { berat badan }(\mathrm{kg})}{\text { Tinggi badan }\left(\mathrm{m}^{2}\right)}
$$

Penilaian Tingkat Kesehatan Anak 
Kesehatan anak ditunjukkan dari tingkat imunisasi dan riwayat sakit anak. Pemberian imunisasi dianjurkan sesuai umur.

Ketepatan waktu imunisasi ditentukan dari setiap jenis imunisasi dasar; skor 3 (imunisasi tepat waktu), skor 2 (munisasi tidak tepat waktu), dan skor 0 (imunisasi belum diberikan sampai umur tertentu). Penjumlahan dari seluruh skor dibandingkan nilai maksimal (dalam persen) merupakan peubah komposit ketepatan imunisasi. Kelengkapan imunisasi ditentukan berdasarkan lengkap tidaknya imunisasi diberikan sesuai umur; skor 1 (imunisasi lengkap), dan skor 0 (imunisasi tidak lengkap).

Data kesakitan anak dihitung dengan skor berdasarkan tingkat kefatalan setiap jenis penyakit, tingkatan sakit dan lamanya sakit (Tabel 7).

Tabel 7

Penilaian Tingkat Kefatalan Penyakit

\begin{tabular}{|l|c|}
\hline \multicolumn{1}{|c|}{ Jenis Penyakit } & Skor $\left.{ }^{*}\right)$ \\
\hline Kulit (bisul, kulit merah, gatal) & 10 \\
Mata & 10 \\
Sariawan, panas dalam & 10 \\
Sembelit, kembung & 10 \\
Gigi & 20 \\
Cacar & 30 \\
Telinga & 40 \\
Bronkhitis, asma, gejala paru-paru & 50 \\
ISPA (batuk, pilek, panas) & 50 \\
Batuk rejan & 60 \\
Campak & 70 \\
Bayi kuning, bilirubin tinggi & 80 \\
Diare, mencret & 80 \\
Kejang & 80 \\
Muntaber & 80 \\
\hline
\end{tabular}

\section{Keragaan Status Gizi Anak}

Berat badan anak saat lahir termasuk baik, rata-rata $3,1 \mathrm{~kg}$. Sebagian besar $(89 \%)$ anak mempunyai berat badan lahir di atas $2,5 \mathrm{~kg}$, dan sisanya termasuk BBLR. Berat lahir anak laki-laki relatif lebih besar dibanding perempuan (Tabel 8). Berat lahir anak yang merupakan hasil kehamilan ditentukan oleh keadaan gizi dan konsumsi pangan ibu pada saat hamil.

Rata-rata BB purnauji menurut kelompok umur yang relatif berbeda antara kedua kelompok perlakuan tidak terlihat pada kurva (kurva KK dan $\mathrm{KI}$ berimpit) menunjukkan pada umur yang sama ratarata berat badan anak adalah sama (Gambar 2). 
Tabel 8

Keragaan Berat Badan Lahir Anak menurut Jenis Kelamin

\begin{tabular}{|c|c|c|c|c|}
\hline \multirow{2}{*}{ Jenis Kelamin } & \multicolumn{2}{|c|}{$\mathrm{KK}(\mathrm{n}=65)$} & \multicolumn{2}{|c|}{$\mathrm{KI}(\mathrm{n}=60)$} \\
\cline { 2 - 5 } & $\mathrm{n}$ & Berat Lahir $(\mathrm{kg})$ & $\mathrm{n}$ & Berat Lahir $(\mathrm{kg})$ \\
\hline - Laki-laki & 35 & $3,15 \pm 0,41$ & 31 & $3,18 \pm 0,57$ \\
$-\quad$ Perempuan & 30 & $2,99 \pm 0,45$ & 29 & $3,02 \pm 0,35$ \\
$-\quad$ Total & 65 & $3,08 \pm 0,43$ & 60 & $3,10 \pm 0,48$ \\
\hline BB lahir (kg) & $\mathrm{n}$ & $\%$ & $\mathrm{n}$ & $\%$ \\
\hline$-\quad<2,5$ & 6 & 9,1 & 3 & 4,6 \\
$-\quad \geq 2,5$ & 59 & 89,4 & 58 & 89,2 \\
$-\quad$ Tidak ditimbang & 1 & 1,5 & 5 & 7,7 \\
\hline
\end{tabular}

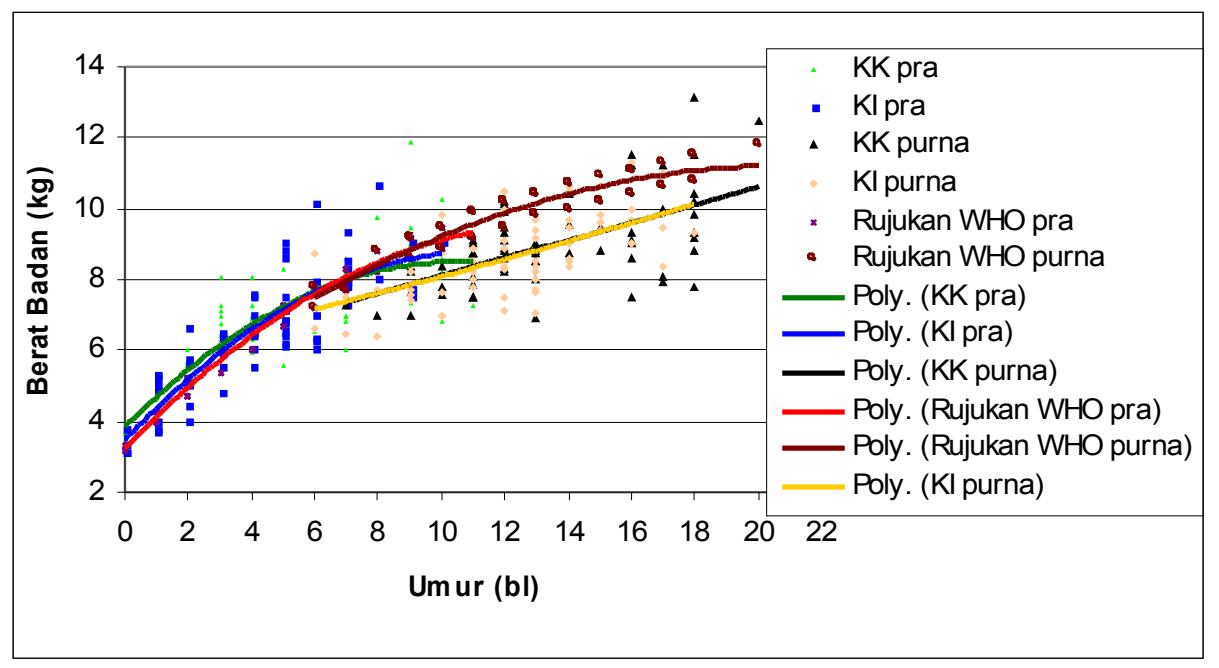

Gambar 2

Berat Badan Anak menurut Umur Prauji dan Purnauji

Dibandingkan dengan rujukan WHO (WHO 1983), berat badan anak pada kedua kelompok relatif lebih tinggi sampai umur 6 bulan. Selanjutnya setelah umur 6 bulan, BB anak tetap naik, namun relatif agak lambat, yang ditunjukkan pada kurva BB anak yang berada di bawah kurva rujukan WHO.

Setelah umur enam bulan, umumnya pemberian ASI mulai berkurang. Sama halnya dengan $\mathrm{BB}$, panjang badan anak pada kedua kelompok (terutama KK) relatif lebih tinggi, ditunjukkan dengan kurva yang berada di atas kurva rujukan, dan pada KK lebih tinggi (Gambar 3). Mulai umur 5-6 bulan, panjang badan anak tetap naik, namun relatif lambat. Panjang badan anak setelah umur enam bulan selalu lebih rendah dibandingkan dengan rujukan.

Status gizi anak prauji dengan ketiga indikator termasuk baik. Sebagian besar anak (92\% KK dan $97 \% \mathrm{KI}$ ) termasuk bergizi baik menurut ukuran $\mathrm{BB} / \mathrm{U}$, menurut ukuran $\mathrm{PB} / \mathrm{U}$, termasuk normal, dan menurut BB/PB, sebagian besar anak normal. Keragaan status gizi anak KK dan KI disajikan pada Tabel 9. 


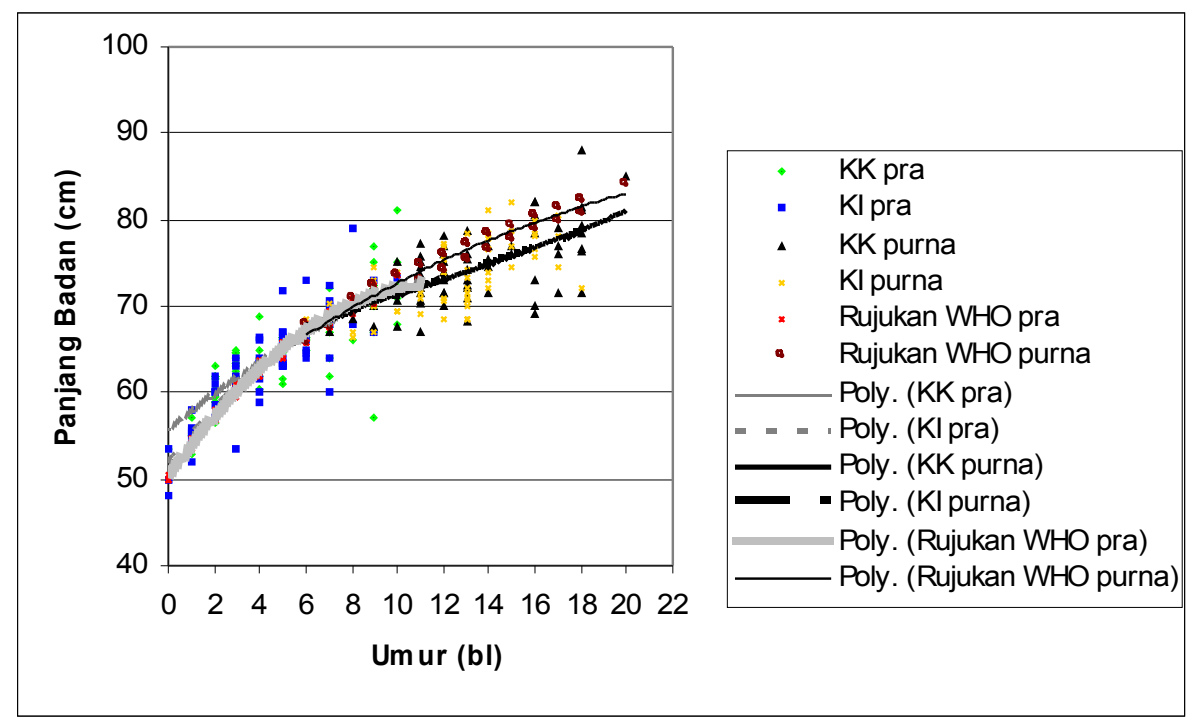

Gambar 3

Panjang Badan Anak KK dan KI menurut Umur Prauji dan Purnauji

Tabel 9

Keragaan Status Gizi Anak Prauji dan Purnauji

\begin{tabular}{|c|c|c|c|c|c|c|c|c|}
\hline \multirow{3}{*}{ Status Gizi } & \multicolumn{4}{|c|}{$\mathrm{KK}(\mathrm{n}=66)$} & \multicolumn{4}{|c|}{$\mathrm{KI}(\mathrm{n}=65)$} \\
\hline & \multicolumn{2}{|c|}{ Prauji } & \multicolumn{2}{|c|}{ Purnauji } & \multicolumn{2}{|c|}{ Prauji } & \multicolumn{2}{|c|}{ Purnauji } \\
\hline & $\mathrm{n}$ & $\%$ & $\mathrm{n}$ & $\%$ & $\mathrm{n}$ & $\%$ & $\mathrm{n}$ & $\%$ \\
\hline \multicolumn{9}{|c|}{ Berat badan/umur } \\
\hline Gizi lebih & 4 & 6,1 & 0 & 0 & 2 & 3,1 & 0 & 0 \\
\hline Gizi Baik & 61 & 92,4 & 59 & 89,4 & 63 & 96,9 & 62 & 95,4 \\
\hline Gizi Kurang & 1 & 1,5 & 7 & 10,6 & 0 & 0 & 3 & 4,6 \\
\hline \multicolumn{9}{|c|}{ Panjang badan/umur } \\
\hline Normal & 64 & 97,0 & 57 & 86,4 & 63 & 96,9 & 57 & 87,7 \\
\hline Pendek & 2 & 3,0 & 9 & 13,6 & 2 & 3,1 & 8 & 12,3 \\
\hline \multicolumn{9}{|c|}{ Berat badan/panjang badan } \\
\hline Gemuk & 1 & 1,5 & 0 & 0 & 2 & 3,1 & 0 & 0 \\
\hline Normal & 64 & 97,0 & 62 & 93,9 & 62 & 95,4 & 62 & 95,4 \\
\hline Kurus & 1 & 1,5 & 4 & 6,1 & 1 & 1,5 & 3 & 4.6 \\
\hline
\end{tabular}

Dibandingkan dengan prauji, status gizi anak purnauji relatif kurang baik, status gizi anak $\mathrm{KI}$ menurut ukuran $\mathrm{BB} / \mathrm{U}$ lebih baik dibanding KK; proporsi anak dengan status gizi baik sebesar $95 \%$ dan $89 \%$. Status gizi anak $\mathrm{KK}$ dan $\mathrm{KI}$ menurut $\mathrm{PB} / \mathrm{U}$ dan $\mathrm{BB} / \mathrm{PB}$ relatif sama. Ada peningkatan proporsi anak tergolong pendek menurut ukuran $\mathrm{PB} / \mathrm{U}$ dari
$3 \%$ menjadi $13 \%$, dan proporsi anak tergolong kurus menurut BB/PB dari 1,5\% menjadi 5-6\%. Pada kedua kelompok, anak kurang dari 12 bulan semuanya berstatus gizi baik, selanjutnya status gizi kurang (BB) U) terdapat pada anak umur $\geq 12$ bulan (Tabel 10). 
Tabel 10

Keragaan Status Gizi Anak menurut Umur Purnauji

\begin{tabular}{|l|r|r|r|r|r|r|}
\hline \multicolumn{1}{c|}{ Kategori } & \multicolumn{3}{c|}{$\mathrm{KK}(\mathrm{n}=66)$} & \multicolumn{3}{c|}{$\mathrm{Kl}(\mathrm{n}=65)$} \\
\cline { 2 - 7 } Status Gizi & $<12 \mathrm{bl}$ & $\geq 12 \mathrm{bl}$ & \multicolumn{1}{c|}{ Total } & $<12 \mathrm{bl}$ & $\geq 12 \mathrm{bl}$ & Total \\
\hline BB/U & & & & & & \\
Gizi Lebih & 0 & 0 & 0 & 0 & 0 & 0 \\
Gizi Baik & 100,0 & 86,0 & 89,4 & 100,0 & 93,0 & 95,4 \\
Gizi Kurang & 0 & 14,0 & 10,6 & 0 & 7,0 & 4,6 \\
\hline PB/U & 93,8 & 84,0 & 86,4 & 95,5 & 83,7 & 87,7 \\
Normal & 6,3 & 16,0 & 13,6 & 4,5 & 16,3 & 12,3 \\
Pendek & & & & & & \\
\hline BB/PB & 0 & 0 & 0 & 0 & 0 & 0 \\
Gemuk & 93,8 & 94,0 & 93,9 & 90,9 & 97,7 & 95,4 \\
Normal & 6,3 & 6,0 & 6,1 & 9,1 & 2,3 & 4,6 \\
Kurus & & & & & & \\
\hline
\end{tabular}

Keterangan: angka dalam persentase (\%)

Dampak Intervensi terhadap Status Gizi Anak

Dampak intervensi terhadap status gizi anak dapat dilihat dari nilai $z$ _skor prauji dan purnauji. Perubahan nilai $z$ _skor menurut indikator $\mathrm{BB} / \mathrm{U}$ adalah sama antara $\mathrm{KK}$ dan $\mathrm{KI}$ yaitu -1,24 sedangkan perubahannya indikator PB/U lebih besar pada KK $(-1,057)$ dibanding KI $(-0,860)$ (Tabel 11).

Tabel 11

Rata-Rata Nilai Z_skor Anak Prauji dan Purnauji

\begin{tabular}{|c|c|c|c|c|c|c|}
\hline Indikator & \multicolumn{3}{|c|}{ KK $(\mathrm{n}=66)$} & \multicolumn{3}{c|}{$\mathrm{KI}(\mathrm{n}=65)$} \\
\cline { 2 - 7 } Status Gizi & Pra & Purna & Perub & Pra & Purna & Perub \\
\hline BB/U & 0,151 & $-1,097$ & $-1,247$ & 0,148 & $-1,092$ & $-1,240$ \\
PB/U & 0,274 & $-0,784$ & $-1,057$ & 0,156 & $-0,703$ & $-0,860$ \\
BB/PB & $-0,069$ & $-0,691$ & $-0,622$ & 0,026 & $-0,759$ & $-0,784$ \\
\hline
\end{tabular}

Perubahan nilai z_skor dengan indikator $\mathrm{BB} / \mathrm{U}$ dan $\mathrm{PB} / \mathrm{U}$ lebih kecil pada umur $\geq 12$ bulan. Perbedaan tersebut terlihat pada KK, yaitu $-1,689$ dan $-1,106(z-B B / U)$, selanjutnya -1.443 dan 0,934 (z-PB/U), sedangkan pada
KI hampir sama. Perubahan nilai z_skor BB/ $\mathrm{U}$ dan $\mathrm{PB} / \mathrm{U}$ lebih rendah pada $\mathrm{KI}$ pada anak umur $<12$ bulan, yaitu $-1,689$ dibanding $-1,306$ (z-BB/U) dan -1,443 dibanding 0,873 (z-PB/U) (Tabel 12).

Tabel 12

Rata-rata Perubahan Nilai Z_skor menurut Umur

\begin{tabular}{|c|c|c|c|c|c|c|}
\hline $\begin{array}{c}\text { Indikator Status } \\
\text { Gizi }\end{array}$ & \multicolumn{3}{|c|}{ KK $(\mathrm{n}=66)$} & \multicolumn{3}{c|}{$\mathrm{KI}(\mathrm{n}=65)$} \\
\cline { 2 - 7 } & \multicolumn{3}{|c|}{ Kelompok Umur (bulan) } & \multicolumn{3}{c|}{ Kelompok Umur (bulan) } \\
\hline Purnauji & $\begin{array}{c}<12 \\
(\mathrm{n}=16)\end{array}$ & $\begin{array}{c}\geq 12 \\
(\mathrm{n}=50)\end{array}$ & Total & $\begin{array}{c}<12 \\
(\mathrm{n}=22)\end{array}$ & $\begin{array}{c}\geq 12 \\
(\mathrm{n}=43)\end{array}$ & Total \\
\hline Z-BB/U & $-1,689$ & $-1,106$ & $-1,247$ & $-1,306$ & $-1,206$ & $-1,240$ \\
Z-PB/U & $-1,443$ & $-0,934$ & $-1,057$ & $-0,873$ & $-0,853$ & $-0,860$ \\
Z-BB/PB & $-0,636$ & $-0,617$ & $-0,622$ & $-0,737$ & $-0,809$ & $-0,784$ \\
\hline
\end{tabular}




\section{Keadaan Kesehatan}

Dua determinan penting yang berpengaruh terhadap status gizi anak adalah intik konsumsi pangan dan keadaan kesehatan, yang dalam peneliitan ini dilihat dari imunisasi dan riwayat sakit. Penilaian mengenai imunisasi mengenai ketepatan waktu dan kelengkapan imunisasi. Dalam hal ketepatan waktu, sebagian besar anak (85\%) telah mendapat imunisasi sesuai dengan umurnya. $\mathrm{Hal}$ ini menunjukkan ibu di kedua kelompok telah menyadari pentingnya imunisasi bagi anaknya. Sejumlah 15\% ibu yang lain memberikan imunisasi kepada anak secara tidak tepat waktu, bahkan ditemukan anak yang sampai 9 bulan belum memperoleh satu jenis imunisasi dengan alasan tidak diperbolehkan oleh keluarga.

Dilihat dari kelengkapan imunisasi yang diberikan pada anak yang telah mencapai umur satu tahun, keadaannya lebih baik pada KI. Dari jumlah anak yang telah mencapai umur satu tahun, proporsi anak yang memperoleh imunisasi dasar secara lengkap pada KI lebih besar dibanding KK yaitu $85 \%$ dan $76,4 \%$ (Tabel 13 ).

Tabel 13

Keragaan Tingkat Imunisasi pada Anak Purnauji

\begin{tabular}{|l|c|c|c|c|}
\hline \multirow{2}{*}{ Tingkat Imunisasi } & \multicolumn{2}{|c|}{ KK (n=66) } & \multicolumn{2}{c|}{ KI (n-65) } \\
\cline { 2 - 5 } & $\mathrm{n}$ & $\%$ & $\mathrm{n}$ & $\%$ \\
\hline Ketepatan Imunisasi Dasar & 66 & 100 & 65 & 100 \\
$-\quad$ Tepat & 56 & 85,6 & 55 & 85,1 \\
$-\quad$ Tidak Tepat & 10 & 14,4 & 10 & 14,9 \\
\hline Kelengkapan Imunisasi Dasar pada umur 1 tahun & 55 & 100 & 54 & 100 \\
$-\quad$ Lengkap & & & & \\
$-\quad$ Tidak Lengkap & 42 & 76,4 & 46 & 85,2 \\
$\quad$ Kelengkapan Imunisasi Dasar saat akhir penelitian & 13 & 23,6 & 8 & 14,8 \\
\hline$\quad$ Lengkap & 62 & 100 & 58 & 100 \\
$-\quad$ Tidak Lengkap & 44 & 71,0 & 48 & 82,8 \\
$\quad$ Imunisasi Hepatitis B & 18 & 29,0 & 10 & 17,2 \\
\hline$\quad$ Ya & 66 & 100 & 65 & 100 \\
$-\quad$ Tidak & 37 & 68,0 & 48 & 74,0 \\
\hline Imunisasi Vitamin A 100.000 SI & 29 & 32,0 & 17 & 26,0 \\
\hline$-\quad$ Ya & 66 & 100 & 65 & 100 \\
$-\quad$ Tidak & 32 & 48,5 & 41 & 63,1 \\
\hline Imunisasi Vitamin A 200.000 SI & 34 & 51,5 & 24 & 36,9 \\
\hline$\quad$ Ya & 50 & 100 & 43 & 100 \\
$-\quad$ Tidak & 20 & 40,0 & 16 & 37,2 \\
\hline
\end{tabular}

Kejadian sakit anak selama tiga bulan yang lalu menunjukkan, proporsi jenis penyakit yang diderita anak terbanyak adalah ISPA dan diare, sedangkan proporsi penyakit campak, penyakit kulit dan gigi hanya $9-17 \%$ (Tabel 14). Kejadian penyakit relatif sama antara $\mathrm{KK}$ dan $\mathrm{KI}$ sekitar $88 \%$, namun pada KI kejadian penyakit ISPA sedikit lebih tinggi daripada penyakit diare. 
Tabel 14

Kejadian Sakit pada Anak menurut Umur Selama Tiga Bulan yang Lalu

\begin{tabular}{|l|c|c|c|c|c|c|}
\hline \multirow{3}{*}{ Jenis Penyakit } & \multicolumn{3}{|c|}{$\mathrm{KK}(\mathrm{n}=66)$} & \multicolumn{3}{|c|}{$\mathrm{KI}(\mathrm{n}=65)$} \\
\cline { 2 - 7 } & $\begin{array}{c}<12 \\
(\mathrm{n}=16)\end{array}$ & $\begin{array}{c}\geq 12 \\
(\mathrm{n}=50)\end{array}$ & $\begin{array}{c}\text { Total } \\
(\mathrm{n}=66)\end{array}$ & $\begin{array}{c}<12 \\
(\mathrm{n}=22)\end{array}$ & $\begin{array}{c}\geq 12 \\
(\mathrm{n}=43)\end{array}$ & $\begin{array}{c}\text { Total } \\
(\mathrm{n}=65)\end{array}$ \\
\hline ISPA & 62,5 & 68,0 & 66,7 & 86,4 & 62,8 & 70,8 \\
Diare & 68,8 & 38,0 & 45,5 & 18,2 & 41,9 & 33,8 \\
Lain-lain (kulit, campak) & 6,3 & 10,0 & 9,1 & 18,2 & 16,3 & 16,9 \\
\hline Semua jenis & 87,5 & 88,0 & 87,9 & 95,5 & 83,7 & 87,7 \\
\hline
\end{tabular}

Keterangan: angka dalam persentase

Faktor-faktor yang Berasosiasi dengan Status Gizi Anak

Berdasarkan analisis pohon regresi terbaik, peubah yang paling dominan berasosiasi dengan status gizi anak $\mathrm{BB} / \mathrm{U}$ dan BB/PB purnauji adalah status gizi ibu (IMT), sedangkan dengan indikator $\mathrm{PB} / \mathrm{U}$ adalah NRKG. Ibu dengan status gizi baik, mempunyai anak berstatus gizi baik pula. Penelitian mengungkapkan ada korelasi positif antara status gizi ibu dan status gizi anak, berkaitan dengan kemampuan ibu memproduksi dan mensekresi ASI.

\section{KESIMPULAN}

Kesimpulan umum dari penelitian ini adalah Model Pendidikan "GI-PSI-SEHAT" yang dikembangkan memadukan aspekaspek gizi, psikososial dan kesehatan yang diberikan kepada ibu, berdampak positif pada konsumsi pangan dan status gizi anak melalui peningkatan perilaku ibu, lingkungan pembelajaran dan pola asuh yang lebih baik.

Secara lebih detil, kesimpulan yang diperoleh dari penelitian ini sebagai berikut:

1. Intervensi pendidikan "GI-PSI-SEHAT" dapat memperbaiki pola konsumsi pangan anak, yang digambarkan dari pemberian makanan anak lebih tepat waktu, dan konsumsi pangan lebih bervariasi.

2. Status gizi anak makin menurun dengan bertambahnya umur. Intervensi pendidikan "GI-PSI-SEHAT" berdampak mengurangi penurunan status gizi terutama pada umur kurang dari satu tahun. Perubahan nilai z_skor $\mathrm{BB} / \mathrm{U}$ dan $\mathrm{PB} / \mathrm{U}$ anak umur $<12$ bulan lebih rendah pada KI, yaitu $-1,306$ (z$\mathrm{BB} / \mathrm{U}$ ) dibanding $-1,689$ dan 0,873 (z$\mathrm{PB} / \mathrm{U}$ ) dibanding $-1,443$.

3. Frekuensi jenis konsumsi pangan merupakan faktor dominan yang berasosiasi secara negatif dengan tingkat konsumsi energi dan protein. Di samping itu status gizi anak dengan indikator BB/U berasosiasi dengan status gizi ibu (IMT) sedangkan dengan indikator PB/U adalah NRKG.

\section{SARAN}

1. Penelitian perlu dilanjutkan pada wilayah perkotaan dan pedesaan dengan karakteristik keluarga, ibu dan anak yang lebih heterogen. Selanjutnya untuk mengetahui dampak intervensi terhadap performance anak secara lebih nyata dan komprehensif, waktu pengamatan terhadap performance anak perlu lebih lama.

2. Intervensi pendidikan "GI-PSI-SEHAT" lebih berdampak positif pada kelompok sasaran dengan pendidikan formal relatif rendah, oleh karena itu model ini dapat ditujukan bagi masyarakat berpendidikan relatif rendah.

\section{RUJUKAN}


1. ACC/SCN. 2000. Ending malnutrition by 2020: an agenda for change in the millennium. Food and Nutrition Bulletin 21(3 Suppl):18-34. Toronto: United Nation University.

2. Behrman JR. 1995. Household behavior, preschool child health and nutrition, and the role of information. Di dalam Andersen PP, Pelletier D, Alderman $\mathrm{H}$, editor. Child Growth and Nutrition in Developing Countries: priorities for action. Ed ke-1. Ithaca and London:Cornell University Press.

3. Birch LL, Fisher JO. 1998. Development of Eating Behaviours Among Children and Adolescent. Pediatrics 101(3 Suppl):539-549.

4. Cerquiera MT, Olson CM. 1995. Nutrition education in developing countries: an examination of recent successful projects. Di dalam Andersen $\mathrm{PP}$, Pelletier $\mathrm{D}$, Alderman $\mathrm{H}$, editor. Child Growth and Nutrition in Developing Countries: priorities for action. Ed ke-1. Ithaca dan London:Cornell University Press.

5. Department of Health. 1995. Report on health and social subjects no. 45. Weaning and the Weaning Diet. London:HMSO.

6. Fieldhouse P. 1995. Food and Nutrition: customs and culture. Ed ke-2. London:Chapman \& Hall.

7. Hardinsyah, Briawan D. 1990 Penilaian dan perencanaan Konsumsi Pangan. Bogor, IPB, Faperta, Jurusan Gizi Masyarakat dan Sumberdaya Keluarga.

8. Hardinsyah, Martianto D. 1989 Menaksir Kecukupan Energi dan Protein serta Penilaian Mutu Gizi Konsumsi Pangan. Jakarta : Wirasari.

9. Isaac S, Michael WB. 1990. Handbook in Research and Evaluation. California:Edits Pub.

10. Kirks BA, Hughes C. 1986 . Long-term behavioral effects of parent involvement in nutrition education. Journal of Nutrition Education 18(5):203-206.

11. Latham MC. 1997. Human Nutrition in the Developing World. Rome:FAO.

12. Mock JP, Jarvis $L$, Jahari $A B$, Husaini MA, Pollit E. 2000. Community Level Determinant of Childgrow in an Indonesian Tea Plantation. Eur J Clin Nutr Supl 54:S28-43.

13. Myers RG. 1995. The Twelve Who Survive: Strengthening Programmes of Early Childhood Development in the Third World. Ed ke-2. Ypsilanti, Michigan: High/Scope Press.

14. Pipes P. 1996a. Nutrition during infancy. $\mathrm{Di}$ dalam Worthington-Roberts BS, Williams SR, editor. Nutrition Throughout the Life Cycle. Ed ke-3. St. Louis:Mosby-Year Book, Inc.

15. Pipes P. 1996b. Nutrition in childhood. Di dalam Worthington-Roberts BS, Williams SR, editor. Nutrition Throughout the Life Cycle. Ed ke-3. St. Louis:Mosby-Year Book, Inc.

16. Powel C. 1999. Overview of early childcare and education programmes and Jamaican case studies. Food and Nut Bulletin 20 (1):181.

17. Rinke WJ. 1986. Holistic Education: A New paradigm for nutrition education. Journal of Nutrition Education 18(4):151-155.

18. Santrock JW. 1997. Life-Span Development. Ed ke-6. Madison:Brown \& Benchmark Publishers.

19. Smith LC, Haddad L. 2000. Overcoming child malnutrition in developing countries - past achievements and future choices. 2020 vision for food, agriculture, and the environment. Discussion Paper 30. IFPRI.

20. Tontisirin KG, Attig, Winichagoon $P$, Young-Aree. 1994. Asian workshop on nutrition education - sharing expertise nutrition and agriculture Review 10. Nutrition Education (FAO, 1994). 
21. Unicef. 1998. The State of the World's Children 1998. New York:Oxford University Press.

22. WHO. 1983. Measuring Change in Nutritional Status:Guidelines for assessing the nutritional impact of supplementary feeding programmes for vulnerable groups. Geneva: WHO.

23. WHO. 1998. Complementary Feeding of Young Children in Developing Countries: a review of current scientific knowledge. Geneva:WHO.

24. WHO. 2003. Implementing The Global Strategy for Infant ang Young Child Feeding. Dep. Of Child and Adolescent Health and Development. Geneva:WHO.
25. Widya Karya Nasional Pangan dan Gizi 2004. VIII. Ketahanan Pangan dan Gizi di Era Otonomi Daerah dan Globalisasi. LIPI. Jakarta.

26. Zeitlin MF et al. 1995. Strengthening the Family: Implications for international development. Tokyo:United Nations University Press. 